Abstracta Iranica Abstracta Iranica

Revue bibliographique pour le domaine irano-aryen

Volume 27 | 2006

Comptes rendus des publications de 2004

«Chaghatai Architecture and the Tomb of Tughluq Temür at Almaliq ». Muqarnas, XXI, (2004), pp. 277-287.

Monik Kervran

(2) OpenEdition

Journals

Édition électronique

URL : http://journals.openedition.org/abstractairanica/6164

DOI : 10.4000/abstractairanica.6164

ISSN : 1961-960X

Éditeur :

CNRS (UMR 7528 Mondes iraniens et indiens), Éditions de l'IFRI

Édition imprimée

Date de publication : 15 mai 2006

ISSN : 0240-8910

Référence électronique

Monik Kervran, « «Chaghatai Architecture and the Tomb of Tughluq Temür at Almaliq ». Muqarnas, XXI, (2004), pp. 277-287. », Abstracta Iranica [En ligne], Volume 27 | 2006, document 253, mis en ligne le 02 janvier 2007, consulté le 25 septembre 2020. URL : http://journals.openedition.org/ abstractairanica/6164; DOI : https://doi.org/10.4000/abstractairanica.6164

Ce document a été généré automatiquement le 25 septembre 2020.

Tous droits réservés 


\title{
«Chaghatai Architecture and the Tomb of Tughluq Temür at Almaliq ». Muqarnas, XXI, (2004), pp. 277-287.
}

\author{
Monik Kervran
}

1 Le khanat chaghatayide, dont le fondateur s'affirma comme le défenseur de la loi tribale mongole fut, au moins à ses débuts, le royaume décentralisé d'un chef nomade, à la différence de celui des Il-Khanides d'Iran et des Yuan de Chine. Pour cette raison peut-être les monuments attribuables à cette dynastie sont-ils peu nombreux. C'est par cette constatation que l'A. introduit son article tout en mentionnant ceux qui nous sont parvenus.

2 Le tombeau de Tughul Temür se rouve à Almaliq, le yailaq (campement d'été) de la branche orientale de l'ulus chaghatayide et ce monument est le dernier vestige médiéval de la ville. Il a été élevé en 771/1369-70, plusieurs années après la mort de Tughul Temür, par les soins de sa femme, jusque là inconnue, Tini Qara Buqa Khatun. Le monument possède une façade en peshtaq, majestueuse par les verticales qui $\mathrm{y}$ dominent et entièrement revêtue de faïences polychromes organisées en décors géométriques et bandeaux d'élégantes inscriptions en blanc sur fond turquoise. Le décor glaçuré de vannerie et d'entrelacs, comparables par sa finesse à celui qui orne le mausolée de Buyan Quli Khan, est le seul exemple connu de ce type hors de Boukhara et Samarqand.

3 Les trois autres façades sont sans décor et B.O.K. remarque la structure originale du monument avec ses trois pièces à l'étage, à l'arrière du monument, destinées aux soufis, aux pèlerins ou aux membres de la famille du défunt. 
INDEX

Thèmes : 5.3. Asie centrale

\section{AUTEURS}

MONIK KERVRAN

CNRS - Paris 